\title{
The effect of foliar top dressing with growth stimulants on potato yield in the southern part of the Volga-Vyatka region of Russia
}

\author{
Svetlana Konstantinova*, and Andrey Fadeev \\ Breeding and seed production group, Federal Agricultural Research Center of the North-East named \\ N. V. Rudnitskogo, 610007, Lenin str., 166a, Kirov, Russian Federation
}

\begin{abstract}
On the experimental basis of the Chuvash Research Agricultural Institute-a branch of the Federal State Budgetary Institution "Federal Agricultural Research Center of the North-East named after N. V. Rudnitsky ", the influence of microbiological growth regulators on biometric indicators, yield and its structural elements of seed plantings of potatoes of the Chaika variety was studied. The use of leaf nutrition preparations of the agrotechnology combine "Azur-Niva LLC" contributed to: an increase in the vegetative mass of potato plants by $42 \%$; an increase in the yield of marketable potatoes from one bush, the number of potato tubers increased by 6.8 pcs., and the mass of tubers by $95 \%$; an increase in potato yield was $32.8 \%$.
\end{abstract}

\section{Introduction}

Over the past ten years, the number of domestic varieties has significantly decreased, their place has been taken by foreign varieties with high yields, but the technology of their cultivation provides for multiple chemical treatments, which negatively affects the cost of potatoes [1]. The problem of the economic feasibility of replacing imported products with domestic analogues is difficult to solve and multifaceted, since it affects the issues of increasing the innovation level, the competitiveness of products, expanding new sales markets, the need to protect the domestic market from foreign competition, and other problems [2].

The annual use of a huge number of different pesticides to protect plants from diseases, pests and weeds, as well as the use of chemical salts of mineral fertilizers in order to obtain more crops of better quality is one of the elements of the degeneration and mass death of the macro-, microflora and fauna of the soil. The balance is disturbed in the process of soil mineralization and humification of organic residues. This leads to the degradation of the fertile soil layer, the loss of active humus and a decrease in the capacity of the humus layer. As one of the options for reducing the use of chemical fungicides and fertilizers, the use of microbiological growth regulators based on strains of living microorganisms and their spores is proposed [3].

\footnotetext{
*Corresponding author: m35y24@yandex.ru
} 
Growth regulators are widely used in potato growing to increase yield and its quality. Studies of scientists have shown that growth regulators have an active influence on the development of plants, the formation of their organs and qualitative characteristics. But growth regulators are not universal means that cause the appearance of new properties and qualities that are not inherent in plants. The effect of these substances is limited by the limits of the plant genotype. Stimulation of plants ' own immunity by growth regulators allows them to induce complex nonspecific resistance to many diseases and adverse environmental factors (drought, low-molecular and high-molecular stresses). Currently, many new chemical compounds with growth-regulating activity have been synthesized. Of all the growth stimulants known to date, only humates can be absolutely definitely said that they have a positive physiological effect on living organisms [4].

It is well known that plants absorb and assimilate nutrients mainly with the help of the root system. In stressful situations - at low or extremely high air temperatures, lack of productive moisture in the soil and atmospheric drought, as well as during periods of rapid growth of the vegetative mass, the absorption of nutrients through the roots is insufficient, and this slows down the growth and development of plants. In such cases, foliar (leaf) fertilizing of plants is a highly effective way to increase the yield of cultivated crops [5]. At the same time, non-root fertilizing is not able to fully compensate for the lack of mineral elements in the soil, especially when large doses of fertilizers are required. Therefore, nonroot top dressing cannot replace the main introduction of nutrients, but can act as a means of correcting the crop, especially when using microelement top dressing $[6,7]$.

Examples of a literary review of the study of non-root nutrition (leaf nutrition) of potato plants in Chuvashia show that at present the study of this issue is extremely relevant, since new high-tech preparative forms are emerging and science does not stand still $[8,9]$.

The purpose of the study is to determine the effectiveness of the use of leaf nutrition preparations of the agrotechnological combine of «Azur-Niva LLC» on the Russian medium-ripe potato variety Chaika in the southern part of the Volga-Vyatka region of Russia.

\section{Methods}

A demonstration field experiment on the study of the effect of growth stimulants and micro-fertilizers was carried out on seed plantings of potatoes of the Chuvash NIISH of the Chaika variety, elite reproduction. A medium-ripened potato variety of the selection of the Falenki breeding station - branch of Federal Agricultural Research Center of the North-East named N.V. Rudnitsky. Characteristic: commercial yield $-242-414 \mathrm{c} /$ ha, maximum yield$454 \mathrm{c} / \mathrm{ha}$, mass of commercial tuber $89-125 \mathrm{~g}$, starch content $12.2-15.3 \%$, marketability $81-91 \%$, shelf life $92 \%$. Resistant to the pathogen of potato cancer, susceptible to golden potato cyst-forming nematode. It has round-oval tubers with medium-deep eyes with a smooth, yellow peel. The flesh is light yellow. Commercial value of the Chaika variety: table purpose, the variety is characterized by high productivity, very good keeping quality, high resistance to viral diseases, drought-resistant $[10,11]$.

The studies were conducted in 2018-2020. The technology, timing, doses and methods of using the drugs are given in Table 1.

Table 1. Terms and scheme of application of drugs in the variant with the technology of leaf nutrition of potato plants.

\begin{tabular}{|c|c|}
\hline $\begin{array}{c}\text { Phases of cultural } \\
\text { development }\end{array}$ & $\begin{array}{c}\text { The name of the drugs and } \\
\text { the norms of their } \\
\text { application }\end{array}$ \\
\hline Processing of seed material & Kultimar $(0.5 \mathrm{l} / \mathrm{t})$ \\
\hline
\end{tabular}




\begin{tabular}{|l|l|}
\hline $\begin{array}{l}\text { Shoots - the beginning of the } \\
\text { regrowth of the green mass }\end{array}$ & Brentax tripl $(0.5 \mathrm{l} / \mathrm{ha})$ \\
\hline $\begin{array}{l}\text { Regrowth of vegetative mass } \\
\text { after hoeing }\end{array}$ & Sprogen first $(0.5-1 \mathrm{l} / \mathrm{ha})$ \\
\hline Formation of flower buds & Brentax Ca $(0.5 \mathrm{l} / \mathrm{ha})$ \\
\hline Flowering and active vegetation & $\begin{array}{l}\text { Aquadon-Micro vegetable }(2 \\
1 / \mathrm{ha})+ \text { Cora NPK2 }(1.5 \mathrm{l} / \mathrm{ha})\end{array}$ \\
\hline $\begin{array}{l}\text { Formation and formation of } \\
\text { tubers }\end{array}$ & Brentax KCa $(1 \mathrm{~kg} / \mathrm{ha})$ \\
\hline
\end{tabular}

Geomorphology of the territory-the area is located in the North-Eastern part of the Volga upland, called the Chuvash plateau. The relief is weakly slope of the South-Eastern exposure. The elevation above sea level is $110 \mathrm{~m}$. the coordinates of the center of the Tsivilsky district can be considered $55^{\circ} 49^{\prime}$ s. w. and $47^{\circ} 29^{\prime}$ w. d. [12]. The soil and climatic conditions of the zone are generally favorable for potato cultivation. The average decadal air temperatures reach positive values already in April, and in the first or second decades of this month, sowing operations usually begin. The abundance of heat and sunlight creates favorable conditions for growing high yields of potatoes The soil of the experimental site is dark-gray forest, with a heavy loam in its granulometric composition. The content of humus in the arable layer is $6.2 \%$, the availability of mobile forms of phosphorus P2O5-238 $\mathrm{mg} / \mathrm{kg}$, potassium $\mathrm{K} 2 \mathrm{O}-132 \mathrm{mg} / \mathrm{kg}$, the soil reaction is close to a neutral $\mathrm{pH}$ of 5.5 [13].

Meteorological conditions of vegetation periods in the years of research differed from each other both for precipitation and for the nature of their distribution, and in the air temperature during the growing season, which allowed us to give an objective assessment of the studied varieties of spring soft wheat. In 2018, the growth and development of field crops took place in conditions of lack of moisture against the background of high temperature conditions throughout the growing season. 2019 was a moderately warm year with a lack of moisture at the beginning of vegetation and high water availability during the tuber formation phase [14]. In 2020, the average air temperature was $15.6^{\circ} \mathrm{C}$ (it was $1.9^{\circ} \mathrm{C}$ above the norm), the amount of precipitation was $325 \mathrm{~mm}$ (138\% of the norm). The sum of active temperatures is $2231^{\circ} \mathrm{C}$. According to the conditions of humidification, the year can be characterized as well humidified (the hydrothermal coefficient is 1.3).

It should be noted that the effectiveness of the combined action of growth regulators is largely determined by soil-zonal conditions and varietal characteristics of agricultural crops. In this regard, the relevance and expediency of conducting a comparative assessment of the drugs used in relation to regional conditions is obvious [15].

The agricultural technique of potato cultivation in the experiment is generally accepted for the Chuvash Republic in the Russian Federation. The predecessor of potatoes is peas. The main tillage is plowing to a depth of 25-27 cm with the PLN-3-35 unit in the autumn after harvesting the previous crop. In the spring, in the third decade of April, moisture closure, harrowing with the BPSH-15 unit was carried out. Application of complex fertilizer NPK 15:15:15 in the second decade of May by the MVU-6 unit with a norm of $300 \mathrm{~kg} / \mathrm{ha}$ in physical weight. To give a finely lumpy structure, the soil was treated with a milling cutter. The tubers of the seed fraction of the Chaika variety were planted in the third decade of May at a soil temperature of $5 \ldots 7^{\circ}$. With tubers sprouted in the light weighing $70-80 \mathrm{~g}$, with a planting rate of 42 thousand tubers per hectare. The planting scheme is $90 \times 20 \mathrm{~cm}$; depth is $7-8 \mathrm{~cm}$. The care of potato plants included two inter-row treatments, hilling, and one chemical treatment against the Colorado potato beetle. On the 55 th and 65 th day of vegetation, dynamic digging was carried out. Cleaning was carried out annually 100-110 days after planting. Treatment of tubers with growth regulators was carried out a day before planting, plants-in the phase of full shoots. Observations and records were 
carried out according to standard methods. Statistical processing of experimental data was carried out by the method of variance analysis according to B. A. Dospekhov [13, 14].

\section{Results}

As a result of phenological observations conducted in 2018-2020, the features of the development of aboveground biomass of potato plants in the dynamics of growth and development with leaf nutrition were revealed. Observations carried out during the growing season of potatoes showed that the greatest increase in the height and weight of potato tops occurred in the variant with leaf nutrition of plants with agrotechnological combine of «Azur-Niva LLC» preparations, presented in Table 2. So, in this variant, the height of the plant was $11 \%$ (on the 55th day) and $15 \%$ (on the 65 th day) higher than in the control. The weight of the tops was 40 and $42 \%$ more, respectively; the number of stems was also on average $15 \%$ more.

Table 2. Biometric indicators of potato growth and development, average for 2018-2020 (per one bush).

\begin{tabular}{|l|c|c|c|c|c|c|}
\hline \multirow{2}{*}{ Option } & \multicolumn{2}{|c|}{ 55th day after germination } & \multicolumn{2}{c|}{ 65th day after germination } \\
\cline { 2 - 7 } & $\begin{array}{c}\text { number } \\
\text { of } \\
\text { stems, } \\
\text { pcs. }\end{array}$ & $\begin{array}{c}\text { height } \\
\text { of } \\
\text { stems, } \\
\text { cm }\end{array}$ & $\begin{array}{c}\text { weight } \\
\text { of the } \\
\text { tops, }\end{array}$ & $\begin{array}{c}\text { number } \\
\text { of } \\
\text { stems, } \\
\text { pcs. }\end{array}$ & $\begin{array}{c}\text { height } \\
\text { of } \\
\text { stems, } \\
\text { cm }\end{array}$ & $\begin{array}{c}\text { weight } \\
\text { of the } \\
\text { tops, }\end{array}$ \\
\hline $\begin{array}{l}\text { Control (without } \\
\text { processing) }\end{array}$ & 4.7 & 50.2 & 321 & 4.9 & 60.8 & 357 \\
\hline $\begin{array}{l}\text { Leaf nutrition of } \\
\text { plants }\end{array}$ & 5.4 & 55.9 & 448 & 5.6 & 69.7 & 508 \\
\hline NSR 0.5 & 0.8 & 6.0 & 130 & 0.5 & 7.2 & 109 \\
\hline
\end{tabular}

The general tendency of potato yield accumulation follows a certain pattern, depending on whether the variety belongs to a certain group of ripeness [16]. It can be disrupted by the specific reaction of some genotypes to external environmental factors. Medium-ripened varieties are distinguished by a small volume of harvest in the first dig, in the future the rate of crop growth increases. Table 3 shows the results of taking into account the dynamics of crop accumulation on average over three years of study.

Table 3. Dynamics of crop accumulation, average for 2018-2020 (per one bush).

\begin{tabular}{|l|c|c|c|c|}
\hline \multirow{2}{*}{ Option } & \multicolumn{2}{|c|}{ 55th day after germination } & \multicolumn{2}{|c|}{ 65th day after germination } \\
\cline { 2 - 5 } & $\begin{array}{c}\text { number of } \\
\text { tubers, pcs. }\end{array}$ & $\begin{array}{c}\text { weight of } \\
\text { tubers, } \mathbf{g}\end{array}$ & $\begin{array}{c}\text { number of } \\
\text { tubers, pcs. }\end{array}$ & $\begin{array}{c}\text { weight of } \\
\text { tubers, } \mathbf{g}\end{array}$ \\
\hline $\begin{array}{l}\text { Control (without } \\
\text { processing) }\end{array}$ & 1.2 & 129 & 2.6 & 224 \\
\hline Leaf nutrition of plants & 2.6 & 342 & 5.6 & 468 \\
\hline Increase & 1.4 & 213 & 3.0 & 243 \\
\hline
\end{tabular}

To analyze the structure of the potato crop, ten bushes were selected from each repetition of the experiment variants. Tubers were weighed and broken into fractions in accordance with the requirements of GOST 33996-2016 for fresh food potatoes. The crop 
structure presented in Table 4 took into account such elements as the number of stems on the plant, the mass of tubers and the number of tubers in the nest.

Table 4. The structure of the yield of one bush of potato plants, the average for 3 years.

\begin{tabular}{|c|c|c|c|c|c|c|c|c|}
\hline \multirow{3}{*}{ Option } & \multicolumn{6}{|c|}{ Tuber fraction } & \multirow{2}{*}{\multicolumn{2}{|c|}{ The amount }} \\
\hline & \multicolumn{2}{|c|}{ More than $80 \mathrm{~g}$} & \multicolumn{2}{|c|}{$50-80 \mathrm{~g}$} & \multicolumn{2}{|c|}{ Up to $50 \mathrm{~g}$} & & \\
\hline & $\begin{array}{l}\text { quantit } \\
\mathbf{y}, \text { pes. }\end{array}$ & $\begin{array}{c}\text { weigh } \\
t, g\end{array}$ & $\begin{array}{l}\text { quantit } \\
\text { y, pes. }\end{array}$ & $\begin{array}{c}\text { weigh } \\
t, g\end{array}$ & $\begin{array}{l}\text { quantit } \\
\text { y, pes. }\end{array}$ & $\begin{array}{c}\text { weigh } \\
t, g\end{array}$ & $\begin{array}{l}\text { quantit } \\
\text { y, pcs. }\end{array}$ & $\begin{array}{c}\text { weigh } \\
t, g\end{array}$ \\
\hline $\begin{array}{l}\text { Control } \\
\text { (without } \\
\text { processin } \\
\text { g) }\end{array}$ & 1.9 & 275 & 6.3 & 377 & 3.6 & 69 & 11.8 & 720 \\
\hline $\begin{array}{l}\text { Leaf } \\
\text { nutrition } \\
\text { of plants }\end{array}$ & 6.4 & 763 & 8.8 & 598 & 2.3 & 44 & 17.5 & 1405 \\
\hline
\end{tabular}

To obtain a high yield of potatoes, it is necessary to remember that potato tubers develop well on fertilized, fertile soil with a light granulometric composition. To do this, it is necessary to create a good thermal, air and water regime in the root-inhabited soil layer and it is recommended to use a variety of growth stimulants [17, 18]. The yield of the medium-ripened potato variety Chaika presented in Table 5 shows that in the variant with leaf nutrition of plants it was $36.97 \mathrm{t} / \mathrm{ha}$, which significantly exceeded the control variant by $9.14 \mathrm{t} /$ ha (at $\operatorname{NSR}_{0.5}=5.4 \mathrm{t} / \mathrm{ha}$ ).

Table 5. Effect of leaf nutrition preparations on potato yield, average for 2018-2020.

\begin{tabular}{|l|c|c|c|}
\hline \multirow{2}{*}{ Option } & \multirow{2}{*}{ Yield, $\mathbf{t} /$ ha } & \multicolumn{2}{c|}{ Increase } \\
\cline { 3 - 4 } & & t / ha & \% \\
\hline $\begin{array}{l}\text { Control (without } \\
\text { processing) }\end{array}$ & 27.83 & - & 32.8 \\
\hline Leaf nutrition of plants & 36.97 & 9.14 & - \\
\hline NSR 0.5 & 5.4 & - & \\
\hline
\end{tabular}

\section{Discussion}

During the research, it was found that the most pronounced differences between the variants appeared already on the 55th day after germination. In the variant with leaf nutrition of plants, the growth rate for 10 days of vegetation was $25 \%$ of the plant height, $13 \%$ of the mass of the tops. In the control, they were lower -21 and $11 \%$, respectively.

Mathematical processing of the obtained data on the biometric indicators of potato plants showed that on the 55th day after germination, the differences between the variants were within the experimental error and on the 60th day in the variant with leaf nutrition significantly exceeded the control.

Already in the first half of the growing season, with a trial digging on the 55th day after germination, the difference in the mass of tubers between the variants was significant. A significant advantage in the accumulation of a marketable crop of tubers at all periods of accounting in comparison with the standard was noted in the variant with leaf nutrition of plants: the number of potato tubers, regardless of the accounting period, was on average 2.2 
times higher than in the control. At NSR ${ }_{0.5}=1.2 \mathrm{pcs}$. /bush - in the first period of digging and at $\mathrm{NSR}_{0.5}=2.6 \mathrm{pcs}$. /bush at the second accounting. The mass of tubers from one bush was also significantly higher than the control - by $213 \mathrm{~g}$ (with $\mathrm{NSR}_{0.5}=186 \mathrm{~g}$ ) in the first term and by $243 \mathrm{~g}$ (with NSR $0.5=205 \mathrm{~g}$ ) in the second term of crop determination.

It should be noted that the growth in the mass of tubers under the bush from the first digging on the 55th day after germination to the second digging on the 65th day after germination in the variant with the use of leaf feeding was slower: the increase was only $36 \%$ whereas in the control $73 \%$. In the variant with treatment, the main increase occurred during the initial period of vegetation - before the onset of 55 days after germination.

Considering the structure of the potato crop, it should be noted that the tested varieties contained a significant number of commercial tubers, and it differs in variants. Studies of the structure of the tuber harvest during harvesting showed that in the variant with leaf nutrition of potato plants, there was a greater yield of a large fraction up to $54.3 \%$, while the percentage of the average (seed) fraction decreased to $42.6 \%$. In the control variant, these indicators of the total yield amounted to $38.2 \%$ (food potatoes) and $52.4 \%$ (seed potatoes), respectively.

Marketable qualities are represented by the marketability of tubers and multiplication coefficients. It is noted that the use of growth regulators for vegetation increases the marketability of potatoes of the Chaika variety from $90.6 \%$ (control variant) to $96.9 \%$. Reproduction coefficients also increase with leaf feeding, both by the number of tubers and by the mass of the tuber nest. The number of tubers of one plant in the variant with leaf nutrition was on average 6.7 pcs. more than in the control, the mass of tubers increased by $95 \%$. It is noted that the use of leaf nutrition preparations of the agrotechnological combine of «AZUR-NIVA LLC» stimulated the increase in the mass of the commodity fraction of potatoes by reducing the mass of non-marketable tubers.

The economic efficiency of the use of leaf nutrition preparations of plants of the agrotechnological combine of «Azur-Niva LLC» was $32.8 \%$. From the economic point of view, the use of growth regulators gives a fairly high net income of up to 260 thousand rubles. compared with the control, including additional - 130 thousand rubles; lower cost of 1 ton -1950 rubles against 3500 rubles and higher level of profitability. The conducted economic analysis showed that the highest level of profitability $(89.7 \%)$ was noted when using preparations of leaf nutrition of plants of the agrotechnological combine of «AzurNiva LLC».

Thus, the results of the conducted studies indicate a positive effect of the use of leaf nutrition preparations of the agrotechnological combine of «AZUR-NIVA LLC» in the soil and climatic conditions of the southern part of the Volga-Vyatka region of Russia.

\section{Conclusion}

The study of the technology of leaf nutrition of Russian potatoes of the Chaika variety with preparations and micro-fertilizers that stimulate growth on gray forest soil in the southern part of the Volga-Vyatka region of Russia in 2018-2020 showed that:

- Preparations of leaf nutrition of the agrotechnology combine "Azur-Niva LLC" increased the vegetative mass of potato plants by $42 \%$;

- There was an increase in the yield of commercial potatoes from one bush - the number of potato tubers increased by 6.8 pcs. , the mass of tubers by $95 \%$;

- The reliable increase in yield was $9.14 \mathrm{t} / \mathrm{ha}$, the economic efficiency was $32.8 \%$, the profitability $-89.7 \%$. 


\section{References}

1. A. G. Tulinov, A. Yu. Lobanov, Agrarian science of the Euro-North-East, 22, 3 (2021)

2. E. A. Maslyukova, E. Y. Ignatova, Innovative development of the agro-industrial complex (2017)

3. I. Y. Ivanova, D. A. Dementyev, Theoretical and applied ecology, 2 (2021)

4. I. A. Borovik, I. M. Latypova, Vegetable growing - from theory to practice (2018)

5. A. E. Novikov, A. S. Mezhevova, A. A. Poddubsky, Yu. N. Pleskachev, O.N. Poddubskaya, International Journal of Advance and Technology, 29, 5 (2020)

6. A. Kumar, Block-3 Nutrient, Water and Weed Management (2021)

7. Sh. A. Younis, K. H. Kim, S. M. Shaheen, V. Antoniadis, Y. F. Tsang, J. Rinklebe, A. Deep, R. J.C. Brown, Renewable and Sustainable Energy Reviews, 152 (2021)

8. I. Y. Ivanova, A. I. Kuznetsov, Bulletin of the Kazan State Agrarian University, 6, 4 (2011)

9. I. Y. Ivanova, Potatoes and vegetables, 17, 1 (2012)

10. A. V. Bakulin, H.P. Savintsev, O. N. Maslakova, N. F. Sintsova, Agricultural science Euro-North-East, 22, 3 (2021)

11. Z. F. Sergeeva, N. F. Sintsova, I. V. Lyskova, T. V. Lyskova, Agricultural science Euro-North-East, 64, 3 (2018)

12. I. Ivanova, S. Ilina, IOP Conference Series: Earth and Environmental Science, 433, 1 (2020)

13. S. Konstantinova, A. Fadeev, IOP Conference Series: Earth and Environmental Science, 548, 7 (2020)

14. I. Ivanova, S. Konstantinova, IOP Conference Series: Earth and Environmental Science, 548, 5 (2020)

15. V. I. Levin, A. S. Petrukhin, Innovations in agriculture: problems and prospects, $\mathbf{1}$ (2016)

16. B. Ahmed, M. Sultana, M. A. H. Chowdhury, S. Akhter, M. J. Alam, Bangladesh Agronomy Journal, 20, 25 (2017)

17. M. Haddad, N.M. Bani-Hani, J.A. Al-Tabbal, A.H. Al-Fraihat, Journal of Food, Agriculture \& Environment, 14, 1 (2016)

18. V.P. Vladimirov, L. M. Egorov, BIO Web of Conferences, 17 (2020) 